\title{
5. Women as Instruments in the Dialectics of the Nation $^{1}$
}

\section{by Sari Roman-Lagerspetz}

\section{Introduction}

G.W.F. Hegel is one of the most influential theorists of the modern nation state. Nevertheless, Hegel's views of women have widely been criticized due to their patriarchal dualism. Feminists, starting from Simone de Beauvoir's The Second Sex (1980 [1949]), have criticized Hegel for excluding women from the sphere of reciprocal recognition between free equals, and his way of consigning women to the sphere of 'nature' and private life in the family. Hegel's views of women have not only been criticized by feminists. Similar criticism has been presented also by e.g. Dudley Knowles $(2002,250)$ and Harry Brod (1992, 174-179). However, Hegel's general theory has also given rise to 'Hegelian feminism' in which Hegelian notions of mutual recognition between the self and the other have been applied to feminist concerns (for different kinds of feminist interpretations of Hegel, see e.g. Hutchings 2003, Hutchings and Pulkkinen 2010, Irigaray 1985, Mills 1996, Pateman 1988, Stafford 1997).

Feminists often emphasize the way Hegel excludes women from the rational, public spheres of the community. Less attention is paid to the way Hegel sees the role of family ethics, the guardians of which are women, as constitutive for the dialectics of the nation. My aim in this article is to demonstrate the way in which Hegel situates gender hierarchy as necessary and constitutive of the rational system of the nation state. What I consider a gendered ethical division of labour is noteworthy: family ethics is necessary for the nation to develop dialectically. This pertains also to how Hegel sees the role of the immature 'Youth' and the importance of wars. The status of women and the uncritical acceptance of mutually non-recognizing nationstates appear to be inter-connected in Hegel's theory. However, the gender hierarchy contradicts with the Hegelian theory of reciprocal recognition and equality between all people. One of the teachings of Hegel's general theory of recognition is that when people project constitutive aspects of themselves to 'enslaved' others, they become alienated from themselves. This results in social pathologies, which often also have a performative power. In the last section of this paper I refer to the insights of Jessica Benjamin to discuss the 
way Hegel's theory contradicts with the idea of reciprocal recognition.

\section{The Tripartite State}

Philosophy of Right (hereafter PR) continues the project, which Hegel started in Phenomenology of Spirit (hereafter PhS), to analyze how the Spirit objectifies itself in the world. One of the aims of this project is to resolve the tensions between desire, morality and ethical life, as well as the tensions between individuality, particularity and universality. The human society develops historically - by overcoming its internal contradictions - towards rationality and freedom. The modern state - which Hegel outlines in PR - is meant to be rational and free. The constitutive aspects of the human mind and the constitutive ways in which humans relate to each other are meant to find expression in it.

In PR Hegel presents his view of the modern society as a tripartite system, differentiated internally into the spheres of family, civil society, and the strictly political sphere, the state in the narrow sense. ${ }^{2}$ The sphere of the family as the immediate substantiality of spirit (PR§158) corresponds to the basic, natural human needs of intimate closeness, love and care. In the family, people form their primary ethical bonds and understand that they need each other in fundamental ways. The familial bonds form the necessary natural foundation for the development of autonomous and independent subjectivity, in which the familial aspects of dependency and immediate unity with others are superseded and reconciled with those of difference, independence and equality in the civil society and in the state. The civil society expresses the principle of difference. In civil society subjects struggle for selfassertion; they have different career-pursuits, and they have particular ambitions concerning, for example, private property. The third sphere, the state, expresses the principle of differentiated unity. The principles of the other two spheres become rationally superseded and maintained ('sublated') in it by collective reflection and communication. In order for the subject to realize its potential for free self-consciousness and to grow into full realization of its own complexity without lapsing into some version of parochialism, it needs to 'find itself' and participate in all these spheres of the society.

These distinct yet organically connected spheres manifest distinct aspects of the ethical Spirit of the society as a whole. The spirit creates distinctions within itself, exhibiting itself as a world articulated into separate spheres. However, as concerns the society as a nation, the spirit also divides itself up into distinct ethical substances, namely into human and 'divine' laws. The gender of the members of the nation assigns individuals into different functional roles within the nation and in the dialectics of the nation, in which 
the male aspects and the female aspects complement each others. This theme, introducing the theme of ethical division of labour, and its problematic implications will be discussed in the following chapters.

\section{The Unconscious Family in the Self-Conscious Society}

In PR (\$165-166) Hegel states that there is a complementary relation between the two sexes, based on natural differences between men and women. The modern state is subdivided into gender-specific spheres, the family (guarded by women) and the public, male spheres of civil society and the state. These distinct spheres express the distinct natures of women and men. The principle of subdivision and its natural basis are made clear in PR:

The difference in the physical characteristics of the two sexes has a rational basis and consequently acquires an intellectual and ethical significance. This significance is determined by the difference into which the ethical substantiality, as the concept, internally sunders itself in order that its vitality may become a concrete unity consequent upon this difference. (PR §165)

Thus one sex is spirit in its self-diremption into explicit personal self-subsistence and the knowledge and volition of free universality, i.e. the self-consciousness of conceptual thought and the volition of the objective final end. The other sex is spirit maintaining itself in unity as knowledge and volition of the substantive, but knowledge and volition in the form of concrete individuality and feeling. In relation to externality, the former is powerful and active, the latter passive and subjective. It follows that man has his actual substantive life in the state, in learning, and so forth, as well as in labour and struggle with the external world and with himself so that it is only out of his diremption that he fights his way to self-subsistent unity with himself. In the family he has a tranquil intuition of this unity, and there he lives a subjective ethical life on the plane of feeling. Woman on the other hand has her substantive destiny in the family, and to be imbued with family piety is her ethical frame of mind. (PR §166. Translation altered. See also the Addition to $\S 166)$

It is important to note that in PR Hegel states that the difference in the physical characteristics (in other words, the natural determinacy) of the two 
sexes has a rational basis, and therefore this difference acquires an intellectual and ethical significance (on this, see e.g. Werner 2010 and Stone 2010). Consequently, man has his actual substantive life in the state, in labour and struggle, while woman's substantive destiny lies in the family and the family piety is her ethical frame of mind. In PR Hegel repeats his idea that the ethics of the family is made visible in Sophocles' tragedy Antigone. In this context he refers to $\mathrm{PhS}$ where he analyzes how this tragedy illustrates the role of woman as the guardian of the family ethics (PR §166; PhS §470-476). Whatever differences there might be between $\mathrm{PhS}$ and $\mathrm{PR}$, on this issue Hegel's views did not change.

In PhS, the role of women and family is discussed in the context of the ancient Greek world. This world is sub-divided into two distinct and opposing spheres, the family and the political state, expressing the principles of individual particularity (family) and universality (polis). This world lacks the sphere of difference (i.e. the sphere of civil society in the modern state). The ancient world is shown by Hegel to be dialectically overcome in the development of the modern tripartite state, expressing more fully the internal constitution of the human subjects and their mutual relations. In PhS Hegel describes family as the realm governed by women and by the specifically feminine ethical spirit. Family embodies the feminine principle, the principle of immediate, undifferentiated unity and the divine ethical law.

The law of the Family is an implicit, inner essence which is not exposed to the daylight of consciousness, but remains as an inner feeling and the divine element that is exempt from an existence in the real world. The woman is associated with these household gods (Penates) and beholds in them both her universal substance and her particular individuality. (PhS §457)

Hegel speaks of the difference between the ethical lives and interests of men and women as follows:

The difference between the ethical life of the woman and that of the man consists just in this, that her vocation as an individual and in her pleasures, her interest is centred on the universal and remains alien to the particularity of desire; whereas in the husband these two sides are separated; and since he possesses as a citizen the self-conscious power to universality, he thereby acquires the right of desire and, at the same time, preserves his freedom in regard to it. (PhS§ 457) 
The husband is sent out by the Spirit of the Family into the community in which he finds his self-conscious being (PhS $\S 460)$

The spirit of 'the Penates,' the spirit of unconscious underworld, is carried by Hegel to illustrate the ethical nature of women and the family from the ancient pagan world up to the modern Christian world and the modern state. The way women as the guardians of the family spirit stay the same through history is shown in PR and in the PhS (to which Hegel refers in PR to illustrate the feminine spirit of the family). The same idea appears recurrently in Hegel's lecture notes on Rechtsphilosophie (Hegel 1974c, 530) as well as in his Lectures on the Philosophy of World History (Hegel 1978, 100, 134). In World History (p. 100) as in PR (§163, 164, 166 [Addition], 173, 257, 341) 'the Penates' are consistently used as a symbol for unconscious particularity (or singularity).

According to Hegel, men are free self-consciousnesses because they are, or they have the potential to be, in control of their own particular subjectivity and desires. They can mediate their particular subjectivity with their universality. They preserve their freedom in regard to their particular individual aspects: they are not controlled and lead by those aspects. Even though male desire can assume parochial and pathological forms, as it can for example take the form of relations of master and slave, it nevertheless ultimately strives for being satisfied in free, equal and rational relations with other (males), capable of the same. Men can learn from their errors, correct them and take a critical rational stance towards their desires, as they can mediate between contradicting dimensions. The private sphere of the family, guarded by women, does not go through historical dialectical changes. While the 'male' parts of the state develop dialectically, the ethical frame of the family stays the same.

Hegel speaks of the female part of the spirit as the 'Nether world.' This is the world of unconscious darkness and unreality, the realm of 'sacred claims' and 'pathos.' This feminine world opposes, and contrasts with, the rational world of men which he also calls the upper world, rational reality, and the realm of the human law (PhS§ 449-452, 474-475). As beholders of the Penates, household gods who in the ancient mythology were thought to watch over a particular household or community, women are drawn inside; they cannot see beyond the limits of their own particular families. Women cannot mediate (in their thinking) with contradicting differences or, for that reason, with the ethical principles of the public spheres. Because women cannot acknowledge contradicting differences and because they thus cannot recognize the Other, the female family spirit remains alien and in a dualistic 
relation to the other spheres. This means, for example, that the male heads of their families have to represent, mediate and interpret the interests of their families in the public spheres of the community. The husband has the potential to see his family as a particular family, and the equal standing of other families, and thus also take into consideration the legitimate interests and contradicting claims of other families.

Both in PR and PhS, there is present a picture of man as a being who struggles with himself in order to create an internally differentiated unity of himself. This requires a reflexive process of self-differentiation: the man must leave the sphere of the family and the immediate unity with other family members. Nevertheless, the family remains a place in which the man has a 'tranquil intuition' of this unity and in which he can always live the family life of emotional loving bonds. Men 'find themselves' (constitutive aspects of themselves) in all three spheres of the society, whereas women stay just in one sphere and in one kind of relation (PR §166). Consequently, women cannot differentiate between the ethics of the family and the ethics of the other spheres of the society. It would require a reflective self-relation to make this tripartite differentiation. The differentiation does not only exist in the external objectivity - as the differentiation between the family, civil society and the state - but it corresponds to the internal differentiation of selfconsciousness. (On this, see Werner 2010 and Roman-Lagerspetz 2009, 123).

The male-specific activities enable society to develop dialectically, from immature forms (e.g. the ancient Greece and the Roman Empire) towards more mature and rational forms (modern nineteenth century Germany of Hegel's time). Family relations are different. In PhS Hegel distinguishes three different kinds of family relations: those between the husband and wife, parents and children, and brothers and sisters. In the relationship between the husband and wife 'one consciousness immediately recognizes itself in another.... [B]ecause this self-recognition is a natural and not an ethical one, it is only a representation, an image of Spirit, not Spirit itself' (PhS §456). Hegel continues: 'In this relationship of the wife there is an admixture of particularity, her ethical life is not pure; but in so far as it is ethical, the particularity is a matter of indifference, and the wife is without the moment of knowing herself as this particular self in the other partner' (§PhS 457).

The relation between parents and children is one of love, care and dutiful reverence towards one another ( $\mathrm{PhS} \S 456)$. Parents raise and educate their children to attain independence of their own. Hegel states about the relations between spouses as well as that between parents and children that: 'both these relationships are confined within the transition and the disparity of the sides which are assigned to them' (PhS §457). In contrast to the other 
two familial relations, the relationship between the brother and the sister is described by Hegel as an 'unmixed one':

They do not desire one another, nor have they given to, or received from, one another this independent being-for-self; on the contrary, they are free individualities in regard to each other. Consequently, the feminine, in the form of the sister, has the highest intuitive awareness of what is ethical. She does not attain to consciousness of it.... (PhS §457)

For Hegel the relationship between the brother and the sister offers for a woman an intuitive experience of a relationship of free, mutual recognition. However, as e.g. Patricia Mills observes, this sort of relationship is possible only for women who have brothers, as this is a natural, family relationship. This relationship takes place within the family of origin mainly before the brother enters the public spheres, where he finds his true substantive selfconsciousness. These spheres the sister as a woman cannot enter (PhS §458459; cf. Mills 1996, 63-66).

Because PhS is basically a developmental narrative in which various imperfect social forms and the corresponding forms of consciousness are superseded by the more developed forms, one might think Hegel is only describing the Greek family. However, the obvious similarity between the description of family relations in $\mathrm{PhS}$ and the relevant paragraphs - quoted above - in PR shows that this is not the case. For Hegel, the family as a 'natural' institution has no history. It does not develop. For example, in Lectures on the Philosophy of World History he writes: 'the family itself lies outside that development from which history takes its source' (p.134). This may sound odd: certainly Hegel must have been aware that family relationships have changed in the course of history. According to my interpretation, Hegel thinks that these changes reflect or result from the changes taking place in the other spheres of society. Unlike, for example, science, law or religion, the family does not develop in a rational way. It does not, so to speak, have a developmental dynamics of its own. Hence, Sophocles' play retains its relevance, and the metaphor of women as beholders of the Penates remains illuminative. In PR (as well as in the lectures on which PR is based) Hegel refers to the relevant passages of PhS. According to my interpretation (and those of feminist critics like e.g. Patricia Mills, Allison Stone and Laura Werner) there seems to be no qualitative difference between how the relation between the spouses is described by Hegel in PhS and how it is described in PR (see e.g. PR §157-159, 163, 167; Mills 1996; Stone 2010; Werner 2010). 


\section{Family, the Youth, and the Nation State}

Hegel associates stability and resistance to dialectical and rational change with the family spirit. The nation as a whole can ultimately change only through use of the capacity for dialectical thinking and self-conscious universality. The family spirit contrasts with this dynamism.

In this context the 'Youth' constitutes an important category. These immature men live in an ambivalent, transitory realm between the family and the public realms of society. They have a similar attitude towards their own nation as women have towards their families. Hegel writes in a somewhat frustrated manner how this type of 'heroic' manhood is admired and supported by women.

Womankind - the everlasting irony (in the life) of community - changes by intrigue the universal end of the government into a private end, transforms its universal activity into a work of some particular individual, and perverts the universal property of the state into a possession and ornament of the Family. Woman in this way turns to ridicule the earnest wisdom of mature age which, indifferent to purely private pleasures and enjoyments, as well as to playing an active part, only thinks and cares for the universal. She makes this wisdom an object of derision for raw and irresponsible youth.... (PhS §475)

Through the immature Youth, feminine family ethics enters the public sphere and assumes a form of nationalist pathos. The Spirit of the Penates is taken to the level of the nation.

The brave youth in whom woman finds her pleasure, the suppressed principle of corruption, now has his day and his worth is openly acknowledged. Now, it is physical strength and what appears as a matter of luck, that decides on the ethical life and spiritual necessity. Because the existence of ethical life rests on strength and luck, the decision is already made that its downfall has come. (PhS § 475)

A feminine state of mind, expressed by the Youth, struggles for a survival as a singular unity because its individual particularity makes up (for it) a universal and absolute end. Like women, the immature men do not differentiate internally between individual singularity and universality. Consequently, they see the nation as a sort of family, which must be 
protected against contradictions. Nevertheless, immaturity plays a significant role in the dialectics of the nation, by driving the state into wars, which Hegel sees as important for the development of the nation:

The movement of human and divine law finds its necessity expressed in individuals in whom the universal appears as 'pathos'.... As a moment of the visible community its activity is not confined merely to the underworld, or to its outer existence, but it has an equally visible existence and movement in the actual nation. Taken in this form, what was represented as a simple movement of the individualized 'pathos' acquires a different look, and the crime and consequent destruction of the community acquire the proper and characteristic form of their existence. (PhS §475)

Although Hegel considers mature self-consciousness the most important feature of the human community, immature consciousness constitutes for him a necessary other power by which the nation understands itself as an individual whole, for example in its international relations. The Hegelian nation is similar to the Hegelian family in that it is something singular; it cannot be part of a larger, internally differentiated unity, e.g. a league of nations of some sort. And because it is normatively singular, it needs a consciousness of itself as singular. This type of consciousness is found in, and produced by, the family Spirit. The complementarity between the immature consciousness and mature consciousness plays a necessary role in the dialectics of the nation. Like the family spirit, the immature nationalist spirit seems to stay the same through the history. In his Introduction to Lectures on the Philosophy of World History Hegel presents a close analogy between the family and the nation:

The spirit of the family - the Penates - constitutes a single substantial being just as much as the spirit of the nation within the state, and ethical life consists in both cases in a common sentiment, a common consciousness.... (p. 100)

The nation possesses in the Youth its nationalist - or, as concerns possible internal conflicts and fragmentation, its separatist - power. This power drives the nation into internal conflicts as well as to wars against other nations, however, conflicts are seen by Hegel as necessary phases in the historical movement of the nation towards enhanced human freedom. In PR (§324), for example, Hegel emphasizes the un-intended positive effects of 
conflicts:

But the state is an individual, and individuality essentially implies a negation. Hence even if a number of states make themselves into a family, this group as an individual must engender an opposite and create an enemy. As a result of war, nations are strengthened.... (PR §324 Addition)

[referring to wars] the ethical health of peoples is preserved in their indifference to the stabilization of finite institutions, just as the blowing of the winds preserves the sea from the foulness which would be the result of a prolonged calm, so also corruption in nations would be the product of prolonged, let alone perpetual peace. (PR §324)

In PhS Hegel's view on the effects of wars is similar to that in PR:

The Spirit of universal assembly and association is the simple and negative essence of those systems which tend to isolate themselves. In order not to let them become rooted and set in this isolation, thereby breaking up the whole and letting the (communal) spirit evaporate, government has from time to time to shake them to their core by war. By this means the government upsets their established order, and violates their right to independence, while the individuals who, absorbed in their own way of life, break loose from the whole and strive after the inviolable independence and security of the person, are made to feel in the task laid on them their lord and master, death. Spirit, thus throwing into the melting-pot the stable existence of these systems, checks their tendency to fall away from the ethical order, and to be submerged is a (merely) natural existence; and it preserves and raises conscious self into freedom and its own power. (PhS §455)

Also, the individual young men of pathos (at least those who survive the conflicts) grow more universal in wars, as they are confronted with the possible destruction of their community. They grow into self-conscious mature men, who work together with other mature men, to raise the nation from its perils and put its pieces together to build a better society. Internal conflicts and wars with other nations constitute a sort of forming of a critical self-consciousness at the level of the spirit of the state. The development of 
the spirit of the nation requires wars, conflicts and struggles in a somewhat similar fashion as that in the development of individual self-consciousness when it struggles with itself and the world to differentiate from the family spirit in order to become a self-consciousness. This seems to be a permanent and cyclical historical process. The dialectics of the nation requires that ever new generations of immature men drive the nation into destruction. Apparently only in this way the nation can change rationally, because one constitutive and permanent aspect of the nation is that it remains a singular individual entity, like the family. There remains through history both the internal tendency to isolation of independent assemblies as well as the tendency of the nation as a whole to stagnate at some historical level.

Somewhat paradoxically, Hegel acknowledges the importance of the aspirations of the Youth, yet, at the same time, he seems to despise them:

The community, however, can only maintain itself by suppressing this Spirit of individualism, and, because it is an essential moment, all the same creates it and, moreover, creates it by its repressive attitude towards it as a hostile principle. However, this principle, being merely evil and futile in its separation from the universal end, would be quite ineffectual if the community itself did not recognize the power of Youth (the manhood which, while immature, still stands within the sphere of individuality) as the power of the whole. (PhS §475)

For Hegel, there are 'futile,' basically feminine powers operating under the surface of the human self-consciousness of the community. These powers are essential. The irrational is needed for the advancement of the rational. Yet, the non-human powers must be repressed by the human powers. The dark powers cannot be turned into rational human forms by the self-critical reflections of the wise men in the synthesizing public realms of society. Nor should they be. Only violence can (temporarily, cyclically) suffocate them. This part of human complexity, this specific dualism between unconsciousness and self-consciousness seems to be necessarily outside of peaceful rational mediation.

In his 'master/slave' theory Hegel argues that the masters externalize into the slaves those parts of themselves which they cannot acknowledge as belonging to themselves. According to my interpretation, this seems to happen in Hegel's own philosophy. The labour done by women, the family and the immature Youth is necessary for the historical advancement of rational humanity in the life of the nation.

Considering his understanding of the importance of the Spirit of the 
Youth it appears that Hegel projects into women the spirit of unconscious individuality, the incapability of internal self-differentiation and, in relations to others, the incapability to recognize contradicting independent others. These (projected) aspects are needed in order for their dualist counterparts recognition of the other, rational humanity - to develop. For Hegel, the Youth, equipped by the female spirit, cannot reflect contradicting thoughts concerning the nation; instead, they can accept only one singular political ideology as the eternal and supreme truth. Paradoxically, because women and the Youth resist dialectical change, they are the very instruments of change.

It appears that Hegel's uncritical views of the nation state as an individual entity with a very restricted capacity to go beyond its limits peacefully and rationally (expressed for example in PR § 330-340 where Hegel rejects Kant's peace plan) has its roots in his theory of the correspondence between the spirit of the family and the spirit of the nation. Although Hegel admits that states have to recognize each others as separate entities, he opposes the idea that nations could recognize each others as equal members of a differentiated unity, in order to establish the Kantian 'perpetual peace.' The feminine spirit of the Penates protects the immediate unity of the members of the nation, provides it with a distinctive identity of its own, and produces the necessary muscles (the Youth) to fight for its survival. The ultimate purpose of the nation is, however, the enhancement of that which is self-conscious, free and human. Through the feminine spirit, every singular historical version of the nation is brought to destruction, so that the rational men (at least those who survive the wars) can build it up again, in versions which are always more rational and free than the previous one.

\section{Hegel and the Unconscious}

According to my interpretation, the Hegelian state includes a gendered division of ethical labour. In the family, individuals of both sexes form their primary, natural ethical bonds of love and care. For women, the family spirit (natural, non-self-conscious immediacy) remains the ethical frame of mind through their lives, whereas for men it forms the natural foundation for the development of self-conscious, independent subjectivity. The ethical difference between men and women is that the family ethics forms one constitutive aspect in the internally differentiated ethical system of men, whereas for women it forms an absolute ethical totality. These two different ethical frames of mind complement each other in the dialectics of the nation. The family forms a sort of ethical 'unconscious' of the community. It has a 
functional role in the rational system of the nation. The 'pathological' incapacity for reciprocal recognition between the self and the contradicting other is instrumental for the dialectical development of the nation. Family unconsciousness remains a permanent feature of the community, untouched by the historical development that takes place in the public (male) spheres of the community. Women represent necessarily restricted ethical particularity; in other words, particularity which is not conscious of its own particularity. This ethical frame of mind drives the community - as a nation - into necessary internal and external conflicts with the contradicting other. By these conflicts the nation can form rational, dialectical syntheses with the contradicting other, thus enabling the continuation of the historical development of the nation.

It seems that Hegel acknowledges that there is something 'pathological' in human individuals, groups and nations. There is a tendency to withdraw from recognizing relations into assemblies of like-minded 'immediacy.' There is reluctance to engage in (and incapacity for) selfreflective thinking and for self-corrective dialectical change. These incapacities exist at individual, communal, and national levels. Families and groups tend to become separatist powers inside the state. The state itself as a nation may become stagnated and resist dialectical change. Hegel situates this sort of pathology especially in family ethics, the ultimate sources and guardians of which are women. Hegel apparently thinks that this kind of pathology is a permanent feature of human communities, shown not only in women and families but also in immature men. Nevertheless, the existence of this pathology is necessary for the gradual development of the state towards enhanced freedom and rationality.

Hegel aimed to build a theory in which the complementary and hierarchical gender system would have a rational explanation. This dualist system is, however, difficult to reconcile with his general theory of freedom, equality and mutual recognition between all people. Especially by the lessons learnt from psychoanalytic theory, we may read Hegel against Hegel and question his attribution of 'unconsciousness' and 'pathos' only to women. There is an aspect of unconsciousness in individuals of both sexes. For example, Jessica Benjamin, a psychoanalyst and philosopher, refers to Hegel's theory of gender-complementarity when she speaks about culturally pervasive notions in which one person or party is not allowed to be an equal subject. One person or party arrogates subjectivity only to himself. Because these models are culturally pervasive and also culturally performative (they tend to produce the phenomena which they intend to describe as external facts) they have influenced, even if not fully determined, the actual formation of the gendering development at both the individual-psychological, familial 
and social levels (Benjamin 1988, 53-54, 171-173).

Benjamin argues that domination does not, however, repress the desire for recognition: rather, it transforms it. Benjamin analyzes how the desire for recognition is transformed in the minds of those who submit to the role of 'slave.' The subordinated ones may remain in love with the ideal of the power that has been denied them. For example, a mother who is denied recognition as an equal subject may end up admiring the heroic power of her son. She projects her desire and (early in her childhood) suppressed omnipotent grandiosity onto her male child (Benjamin 1988, 219222; Benjamin 1995, 68). This resonates with how Hegel sees women admiring and fuelling up the spirit of heroic pathos in the young men.

For Benjamin, the possibility to overcome the gender duality is to accept the permanent presence of conflicting tendencies within the self, and the presence of some desires or drives which we probably cannot fully know, yet, with which we can learn to live in an ethical way. The (pathological) alternative would be to consider some aspects of ourselves as threats to our rationality and project them onto some others, for example to women or ethnic others. Benjamin also thinks that the culturally dominant explanations of the primary bond between mother and child should be questioned. She sees that there is no need to think, for example, that aspects of mutual recognition and intersubjectivity (instead of total symbiosis) would not exist already at a very early level of childhood between mother and child. The picture of what it is to be a mother, and a woman, should be made more complex, allowing the critical questioning of the identification of mothers and women with unconsciousness and subject-threatening immediacy and symbiosis (Benjamin 1988, 170-181). Benjamin's insights imply that the repudiation of the mother - and those aspects of love, care and nurturance associated with her - may create a norm of a rational subject who lacks ethical responsibility and sensitivity also in questions of war and peace. The attitude Hegel describes in his works, to see violence and wars as a necessity for the advancement of humanity, seems to be an example of this kind of ethical irresponsibility.

\section{Conclusion}

I think that Hegel's theory of mutual recognition contains an extremely important truth. I also believe that his theory of the modern society contains important insights. Clearly, he understood something essential about the role of the unconscious. It is striking that his views of the gender roles were so incompatible with his theories. Moreover, Hegel did not only uncritically accept the prevailing views of gender roles but he also tried to actively 
develop a theoretical justification for those prejudices. Perhaps the most important lesson to be learned from his errors is this: no theoretical conception, however critical and sophisticated, can alone save us from the dangers of misrecognition. The critical question is: What other beliefs and convictions does one hold? For example, organic conceptions of the society or the nation may threaten mutual recognition between individuals if they place individuals into functional or strategic roles inside the organic whole, based on natural or anatomic differences like gender.

Sari Roman-Lagerspetz (romanlag@mappi.helsinki.fi) has a $\mathrm{PhD}$ in Political Science and works in the "Pathologies of Recognition"-project of the Academy of Finland. She has published articles in political theory, gender-studies and philosophy of religion and is a feminist and human rights activist.

\section{Bibliography}

Benjamin, J. (1988) Bonds of Love New York: Pantheon Books

Benjamin, J. (1995) Like Subjects, Love Objects New Haven and London: Yale University Press

Brod, H. (1992) Hegel's Philosophy of Politics San Francisco: Westview Press

de Beauvoir, S. (1980 [1949]) The Second Sex (trans. H. Parshley) New York: Vintage

Hegel, G. W. F. (1977 [1807]) Hegel's Phenomenology of Spirit (trans. A. V. Miller) Oxford: Oxford University Press

Hegel, G. W. F. (1967 [1821]) Hegel's Philosophy of Right (trans. T. M. Knox) Oxford: Oxford University Press

Hegel, G. W. F. (1974a [1824-25]) Vorlesungen über Rechtsphilosophie 1818-1831, band 4: Philosophie des Rechts nach der Vorlesungsnachschrift K. G. von Griesheims, 1824/25 (ed. K.-H. Ilting) Stuttgart: Frommann-Holzboog

Hegel, G. W. F. (1974b [1821]) Vorlesungen über Rechtsphilosophie 1818-1831, band 4: Die "Rechtsphilosophie" von 1820 mit Hegel's Vorlesungsnotizen 1821 (ed. K.-H. Ilting) Stuttgart: Frommann-Holzboog 
Hegel, G. W. F. (1974c [1822-23]) Vorlesungen über Rechtsphilosphie 1818-1831, band 3: Philosophie des Rechts nach der Vorlesungsnachschrift von H. G. Hotho 1822/23 (ed. K.-H. Ilting) Stuttgart: Frommann-Holzboog

Hegel, G. W. F. (1978 [1822-30]) Lectures on the Philosophy of History. Introduction: Reason in History (trans. H. B. Nisbet) Cambridge: Cambridge University Press

Hutchings, K. (2003) Hegel and Feminist Philosophy Cambridge: Polity Press

Hutchings, K. \& Pulkkinen, T. (eds.) (2010) Hegel's Philosophy and Feminist Thought New York: Palgrave Macmillan

Irigaray, L. (1985) Speculum of the Other Woman (trans. G. C. Gill) New York: Columbia University Press

Knowles, D. (2002) Routledge Philosophy Guidebook to Hegel and the Philosophy of Right London: Routledge

Mills, P. J. (1996) 'Hegel's Antigone' in P. J. Mills (ed.) Feminist Interpretations of G.W.F. Hegel PA: Penn State University Press, pp. 59-88

Pateman, C. (1988) The Sexual Contract Cambridge: Polity Press

Roman-Lagerspetz, S. (2009) 'Striving for the Impossible. The Hegelian background of Judith Butler' Acta Politica vol. 36, Helsinki: Department of Political Science, University of Helsinki

Stafford, A. M. (1997) 'The Feminist Critique of Hegel on Women and the Family' Animus vol. 2, pp. 64-92

Stone, A. (2010) 'Matter and Form: Hegel, Organicism, and the Difference between Women and Men' in K. Hutchings \& T. Pulkkinen (eds.) Hegel's Philosophy and Feminist Thought New York: Palgrave Macmillan, pp. 211-232

Werner, L. (2010) 'The Gender of Spirit: Hegel's Moves and Strategies' in K. Hutchings \& T. Pulkkinen (eds.) Hegel's Philosophy and Feminist Thought New York: Palgrave Macmillan, pp. 195-209 


\section{Endnotes}

${ }^{1}$ I am grateful to the members of the Pathologies of Recognition-project, funded by the Academy of Finland, for valuable discussions. Special thanks to Arto Laitinen, Arvi Särkelä and Heikki Ikäheimo. I am also indebted to Ilmari Jauhiainen for his inspiring comments and Eerik Lagerspetz for useful discussions. I thank Alison Beale warmly for excellent proofreading!

${ }^{2}$ Hegel has several notions of 'the state.' In PR, the term is used mainly to denote the strictly political sphere; courts of justice, for example, do not belong to the state but to the civil society. In other contexts, however, 'the state' refers to a territorially limited, organized totality of people. 